\title{
The Use of Biodegradable Mulches in Pepper Production in the Southeastern United States
}

\author{
Jenny C. Moore and Annette L. Wszelaki ${ }^{1}$ \\ Department of Plant Sciences, University of Tennessee, 2431 Joe Johnson \\ Drive, Knoxville, TN 37996
} Additional index words. biodegradable plastic mulch, paper mulch, soil exposure, crop yield,
weed pressure, nutsedge

\begin{abstract}
Plasticulture systems with polyethylene (PE) mulch and drip tape are common for production of peppers (Capsicum annuum L.) in the United States because of their soil warming, moisture conservation, and other advantageous effects. However, disadvantages include disposal costs and plastic pollution of the environment and temperature stress in warm climates with black mulch. Use of biodegradable plastic mulches (BDMs) is becoming more common, as they provide the same benefits of PE mulch without the disposal problems. In 2017 and 2018, we conducted experiments in Knoxville, TN, comparing production of pepper fruit with five different BDM [one white-on-black (WOB) and four black], one black PE mulch, one brown creped, paper mulch, and bare ground control treatments. We also measured the durability and effectiveness of weed suppression of the different mulches over the growing season compared with a handweeded bare ground control. Most mulches were degraded, with $40 \%$ to $60 \%$ of the soil exposed by the end of the season, with the exception of the paper mulch, which was completely degraded at the end of both seasons. Yields were similar among treatments in 2017, with the exception of Naturecycle, which had the lowest yield. Weed pressure was severe, especially in 2018, largely due to early penetration of all mulches except paper by nutsedge. Due to the early and season-long weed pressure and heat stress in black mulches, there were fewer healthy plants in all black-colored mulch treatments in 2018 , leading to reduced yields in these treatments. Paper mulch was the only treatment that prevented nutsedge growth; therefore, this treatment and the hand-weeded bare ground treatment had the greatest yields in 2018 . WOB also had yields comparable with paper and bare ground plots in $\mathbf{2 0 1 8}$, likely due to the cooling effect of the white mulch. The results suggest that in hot climates and in fields infested with nutsedge, paper mulches perform best for midseason pepper cultivation due to the cooling effects and superior weed control.
\end{abstract}

Most bell peppers (Capsicum annuum L.) produced in the United States are grown on raised beds with drip irrigation and PE mulch, and the production value has increased from \$514 million in 2012 to more than \$641 million in 2017 (USDA NASS, 2018). PE mulch can be beneficial for intensive vegetable and specialty crop production by increasing yields and fruit quality, reducing weed pressure, warming the soil for early season production, and reducing water evaporation

\footnotetext{
Received for publication 5 Feb. 2019. Accepted for publication 17 Mar. 2019.

This article is based on work that is supported by the National Institute of Food (NIFA) and Agriculture, U.S. Department of Agriculture, under award number 2014-51181-22382, and NIFA Hatch project 1008680 .

We thank Elizabeth Cousins, B.J. DeLozier, Cody Fust, Payton Myers, Jake Seeley, and Madelyn Williams for invaluable help with field work and Arnold Saxton for indispensable help with statistics. Any opinions, findings, conclusions, or recommendations expressed in this article are those of the authors and do not necessarily reflect the view of the U.S. Department of Agriculture.

${ }^{1}$ Corresponding author. E-mail: annettew@utk.edu.
}

largely unknown (Brodhagen et al., 2017; Rillig, 2012). There are some reports, however, that plastic residues also may be harmful to soil ecosystems (Bläsing and Amelung, 2018; Steinmetz et al., 2016). A metaanalysis by Gao et al. (2019) found that plastic film residue in soil at or below $240 \mathrm{~kg} / \mathrm{ha}$ did not affect crop yield, but when plastic residue was greater than $240 \mathrm{~kg} / \mathrm{ha}$, yield was significantly reduced.

BDMs provide many of the same benefits as PE mulch while avoiding these disposal problems, as they can be tilled into the soil at the end of the season or retrieved and then composted. Jambeck et al. (2015) estimate that if the top 20 countries (ranked by mass of improperly managed plastic waste) were to increase proper disposal of plastic waste, the mass of waste potentially polluting terrestrial and aquatic environments could decrease $41 \%$ by 2025 . Changing from PE to BDM could help the agricultural industry reach this needed reduction in plastic waste.

As mentioned, a major benefit of $\mathrm{PE}$ mulch and BDM is usually reduced weed pressure; however, nutsedge species [purple nutsedge (Cyperus rotundus L.) and yellow nutsedge (Cyperus esculentus L.)] can penetrate both PE mulch and BDMs (Webster, 2005). Purple nutsedge is a pernicious weed and has been reported from more locations in the world than any other weed, affecting 52 different crops in 92 different countries (Holm et al., 1977). Sometimes the only economical option available to growers with nutsedge-infested fields is to abandon highvalue vegetable crops for a cereal or forage crop that can better compete with the weed (Cirujeda et al., 2012; Wang et al., 2009). Webster (2005) observed that PE mulch use can actually lead to expansion of underground purple nutsedge patches compared with non-mulched controls and that tears and holes caused by nutsedge allow other weeds to germinate.

Nutsedge can be especially harmful for pepper production, as emergence of only five yellow nutsedge plants per $\mathrm{m}^{2}$ can reduce bell pepper yield by $10 \%$ (Motis et al., 2003). Weeds such as nutsedge pose a significant challenge to successful use of PE mulch and BDMs for vegetable production. In fact, if a field is infested with nutsedge, a grower may not be able to successfully use PE mulch or BDMs. Numerous field studies have examined ways to control nutsedge in PE-mulched peppers (e.g., Bangarwa et al., 2009; Motis et al., 2003, 2004; Santos et al., 2007). One study has shown that coated paper mulch can reduce nutsedge pressure in pepper (Shogren and David, 2006). Others have also observed that paper mulch is one of the few mulches that can effectively suppress nutsedge in other crops (Anzalone et al., 2010; Cirujeda et al., 2012; Shogren and Hochmuth, 2004), as nutsedge can penetrate plastic mulch four times as thick as commonly used commercial mulches (Webster, 2005).

For BDMs to be a viable alternative, they must provide similar benefits to PE without the disposal and environmental issues. The 
objectives of this study were to 1) compare the yield of pepper fruit among five different BDMs compared with PE mulch, paper mulch, and bare ground treatments and 2) measure the durability and effectiveness of these mulches for weed suppression over the growing season compared with a hand-weeded bare ground control.

\section{Materials and Methods}

Experimental location. This study was carried out in 2017 and 2018 at the University of Tennessee, East Tennessee AgResearch and Education Center, Plant Sciences Unit in

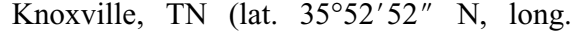
$83^{\circ} 55^{\prime} 27^{\prime \prime} \mathrm{W}$, elevation $270 \mathrm{~m}$ ). The field site was located in the subtropical southeast United States with an average daily temperature of $23{ }^{\circ} \mathrm{C}$, an average relative humidity (RH) of $73 \%$, and an average rainfall of $421 \mathrm{~mm}$ (30-year average; Arguez et al., 2010). The site has moderately well-drained Shady-Whitwell complex soil characterized as a fine-loamy, thermic Typic Hapludult with a $\mathrm{pH}$ of 6.4 and $1.3 \%$ organic matter. A winter wheat cover crop preceded the experiment both years, and other records of field history for 2015 to 2016 can be found in Ghimire et al. (2018).

Experimental design and planting. The mulch treatment plots were established in 2015 in a completely randomized block design with four replications. Treatment plot assignments did not change across the years (2015-2018) to avoid cross-treatment mulch and soil contamination as BDMs are tilled into the soil at the end of every cropping season. Eight treatments (Table 1) were randomized within each main plot in 2015 . The 2015 and 2016 experiment, with pumpkin as the test crop, is described in Ghimire et al. (2018). The WOB mulch treatment, with the white surface facing up and the black surface touching the soil, was added in 2017 replacing a BioAgri treatment that was removed from the field at the end of the seasons in 2015 and 2016. Mulch was laid by machine (Model 2600 Bed Shaper; Rain-Flo Irrigation, East Pearl, PA) in all plots at the time of bed shaping on 23 May 2017 and 24 May 2018. 'Aristotle' pepper (a green bell, Seedway, LLC, Hall, NY) was planted both years and was chosen for its resistance to bacterial leaf spot races 1 to 3 and tolerance to Phytophthora and Tobamovirus. Plots were five beds wide and 9-m long, and beds were spaced $2.1 \mathrm{~m}$ center-to-center, which is greater than typical grower production practices in this area due to concurrent experiments as described previously. In-row spacing was $0.46 \mathrm{~m}$ with plants in a double staggered row, with 18 plants per row and 36 plants per plot. Peppers were seeded in the greenhouse in 128-cell trays on 21 to 22 Apr. 2017 and 16 to 17 Apr. 2018, and transplanted in the field on 25 May 2017 and 29 May 2018. Following transplanting, the remaining plants were moved to 54-cell trays and kept in a greenhouse for replacing missing or dead transplants in the field for up to 4 weeks following the initial transplant date. At the end of each season (2015-18), the PE was removed from the field, and BDMs and paper mulch were tilled into the soil.

Fertilizer and irrigation. After disking the field, $56 \mathrm{~kg} \mathrm{~N} / \mathrm{ha}, 112 \mathrm{~kg} \mathrm{P} / \mathrm{ha}$, and $112 \mathrm{~kg}$ $\mathrm{K} / \mathrm{ha}$ were broadcast over the entire field with a 3-m drop spreader, then the field was worked with a field cultivator to incorporate the fertilizer and prepare an even seedbed for planting. Drip irrigation tape (T-Tape, Model \#508-08-340, $0.20 \mathrm{~mm}, 20$-cm emitter spacing, $4.23 \mathrm{~L} / \mathrm{min} / 100 \mathrm{~m}$ flowrate, San Diego, CA) was laid simultaneously with the mulch treatments. Weekly fertigation applications of calcium nitrate $(28 \mathrm{~kg} / \mathrm{ha}$ rate $)$ and potassium nitrate $(22 \mathrm{~kg} / \mathrm{ha}$ rate) were applied starting within a week after transplanting and continuing until the last harvest for a total of $43 \mathrm{~kg} \mathrm{~N} / \mathrm{ha}$ and $62 \mathrm{~kg} \mathrm{~K} / \mathrm{ha}$ applied through fertigation each season.

Weather data. Air temperature, rainfall, and RH were collected from the Plant Sciences Unit weather station, which was $10 \mathrm{~m}$ away from the pepper field. The precipitation sensor on the field weather station was malfunctioning at times during both growing seasons, so precipitation data were taken from the U.S. National Oceanic and Atmospheric Administration station located on the farm $533 \mathrm{~m}$ from the field site (NOAA, 2018). Soil temperature and moisture sensors (5TM; Decagon Devices, Inc., Pullman, WA) were installed in bed 3 of each plot in one replicate block at $10 \mathrm{~cm}$ and $20 \mathrm{~cm}$ depths and data were recorded at $60 \mathrm{~s}$ intervals and averaged hourly using data loggers (EM50G; Decagon Devices, Inc.).
Weed management. Planting holes, bed shoulders, and bare ground plots were hand weeded as needed throughout both growing seasons, from 7 June through 1 Aug. 2017 and 5 June through 26 July 2018. Weeds in alleys were controlled with herbicides (RoundUp WeatherMax; Monsanto, St. Louis, MO, 2.3-2.9 L.ha ${ }^{-1}$ ).

Mulch deterioration ratings and weed assessments. Mulch degradation in each plot during the cropping season was rated visually, two times per month (about on the first and 15 th of each month). Ratings were done by the same person for consistency both years. Mulch degradation was assessed each time as percent soil exposure (PSE), where $0 \%$ represents completely intact mulch and fully covered soil and 100\% represents fully exposed soil. Rating was in $1 \%$ increments until $20 \%$ exposure and in $5 \%$ increments thereafter. PSE was measured in the center $1 \mathrm{~m}$ of bed 3 in each plot.

Weed data were collected from a 1-m block of either bed 2 or 4 (determined through randomization) three times during each season: 3 weeks after transplanting, midseason, and $\approx 2$ weeks before the last harvest. The first sample was in the center of the bed, the second was east of center, and the last was west of center so that a new area was sampled for each rating. Weeds were clipped at the soil surface and counted by species. Total fresh aboveground biomass for all weeds combined per plot was recorded. Samples were then dried at $62{ }^{\circ} \mathrm{C}$ for $48 \mathrm{~h}$ to determine total dry mass.

Plant health ratings. Plant health was rated on 11 July and 9 Aug. in 2017 and on 3 July and 14 Aug. in 2018. All plants in the data bed were visually classified as healthy (full, dark green canopy), small but otherwise healthy (dark green canopy, but noticeably small), stunted (poor color, very small), or dead/missing.

Fruit harvest and yield. Peppers were harvested at the mature green stage weekly 26 July to 19 Sept. 2017 and 16 July to 27 Aug. 2018 from all plants in the center bed of each plot. Marketable pepper fruit were sorted into size classes: small $(<7.0 \mathrm{~cm})$, medium $(7.0-7.6$ $\mathrm{cm})$, large $(7.6-8.9 \mathrm{~cm})$, extra large $(8.9-10.2$ $\mathrm{cm})$, jumbo $(>10.2 \mathrm{~cm})$, and choppers (fruit that are smaller or misshapen but otherwise marketable). Fruit in all size classes were then

Table 1. Mulch treatments in BDM field experiment in Knoxville, TN, 2017-18.

\begin{tabular}{|c|c|c|c|c|}
\hline Treatment & Manufacturer & Thickness $(\mu \mathrm{m})^{\mathrm{z}}$ & Key product ingredient(s) & Product color \\
\hline \multicolumn{5}{|l|}{ 1. Bare ground } \\
\hline 2. Polyethylene (PE) & Filmtech, Allentown, PA & 25.4 & Polyethylene & Black \\
\hline 3. WeedGuardPlus (WGP) & Sunshine Paper, Aurora, CO & 240.0 & Creped paper & Light brown \\
\hline 4. $\operatorname{Bio} 360$ & $\begin{array}{l}\text { DuBois Agrinovation, Saint-Rémi, } \\
\text { Quebec, Canada }\end{array}$ & 18.0 & $\begin{array}{l}\text { Polyesters blends with or } \\
\text { without starch }\end{array}$ & Black \\
\hline 5. Organix A.G., black & Organix Solutions, Maple Grove, MN & 17.8 & BASF Ecovio (PBAT + PLA) & Black \\
\hline 6. Naturecycle & Custom Bioplastics, Burlington, WA & 25.4 & Starch-polyester blend & Black \\
\hline 7. Exp-PLA/PHA & Experimental Film ${ }^{\mathrm{y}}$ & 25.0 & Ingeo PLA/Mirel amorphous PHA & Black \\
\hline $\begin{array}{l}\text { 8. Organix A.G., White-on-black } \\
\text { (WOB) }\end{array}$ & Organix Solutions, Maple Grove, MN & 17.8 & BASF Ecovio (PBAT + PLA) & $\begin{array}{l}\text { White on top, } \\
\text { black on bottom }\end{array}$ \\
\hline
\end{tabular}

${ }^{\mathrm{z}}$ Divide by 25.4 to convert to mils.

yPrepared for this project by Metabolix, Inc., Cambridge, MA

$\mathrm{BDM}=$ biodegradable plastic mulch; $\mathrm{PBAT}=$ poly(butylene adipate-co-terephthalate $)$ PLA $=$ polylactic acid; $\mathrm{PHA}=$ polyhydroxyalkanoate. 
counted and weighed. Culls were sorted by primary cause of unmarketability, then were counted and weighed by category. Unmarketable categories included sunscald, insect damage, disease, blossom end rot, rot or other (too small, immature, mechanical or string damage, nutsedge damage, broken branches, russetting, animal damage, and checking).

Data analysis. All data were subjected to analysis of variance using generalized linear mixed model (GLIMMIX) procedure in SAS (Statistical Analysis System Version 9.2 for Windows; SAS Institute, Cary, NC). Data were analyzed as a completely randomized block design. The MMAOV macro (Saxton, 2010) in SAS was used to build all PROC GLIMMIX procedures and the slice statement was used to simplify means comparison by dates. The assumption of normality was assessed using the Shapiro-Wilk test $(\mathrm{W}>0.80)$ and homogeneity of variances were assessed with Levene's test $(\alpha=0.05)$. Fisher's least significant difference test ( $\alpha=0.05$ ) was used to compare treatment means for significant differences. When treatment by year and treatment by date interactions were significant, data are presented separately by year or date. As no transformation satisfied the assumptions of normality and homogeneity of variance for yield, weed count, and weed dry mass data, a nonparametric transformation (PROC RANK in SAS) was used for mean separations; however, raw means are reported. Percentage data were analyzed using the GLIMMIX procedure in SAS with a binomial distribution.

\section{Results}

Weather data. Total rainfall for the growing season (late May to early September) was $481 \mathrm{~mm}$ for 2017 and $437 \mathrm{~mm}$ for 2018. The 2-year daily average air temperature for the growing seasons was $24{ }^{\circ} \mathrm{C}$ and $\mathrm{RH}$ was $81 \%$. Daily average, maximum, and minimum air temperature for both seasons are shown in Fig. 1. Daily average soil temperatures $\left({ }^{\circ} \mathrm{C}\right)$ at $10 \mathrm{~cm}$ for both seasons are shown in Fig. 2. Soil temperatures were not recorded for the WOB treatment, due to the project's original instrumentation setup in 2015.

Percent soil exposure. Overall PSE was similar for 2017 and 2018, with most mulches reaching $40 \%$ to $60 \%$ soil exposed by the end of the season, except for WeedGuardPlus (WGP), which was completely degraded by the end of both seasons (Fig. 3). Another exception was polylactic acid/polyhydroxyalkanoate (PLA/ PHA), which broke down much more rapidly in 2018 than in 2017, with a soil exposure of more than $40 \%$ only $17 \mathrm{~d}$ after transplanting in 2018 and almost $100 \%$ soil exposure by the end of the 2018 season (Fig. 3). PE mulch remained the most intact, followed closely by WOB, with both treatments having about $16 \%$ to $20 \%$ soil exposed by the end of the season in 2017 and just less than $40 \%$ soil exposed by the end of the season in 2018.

Weed assessment. There were significant treatment and year as well as treatment, date, and year interactions $(P<0.0001$ for all $)$. Data are interpreted by treatment with dates and
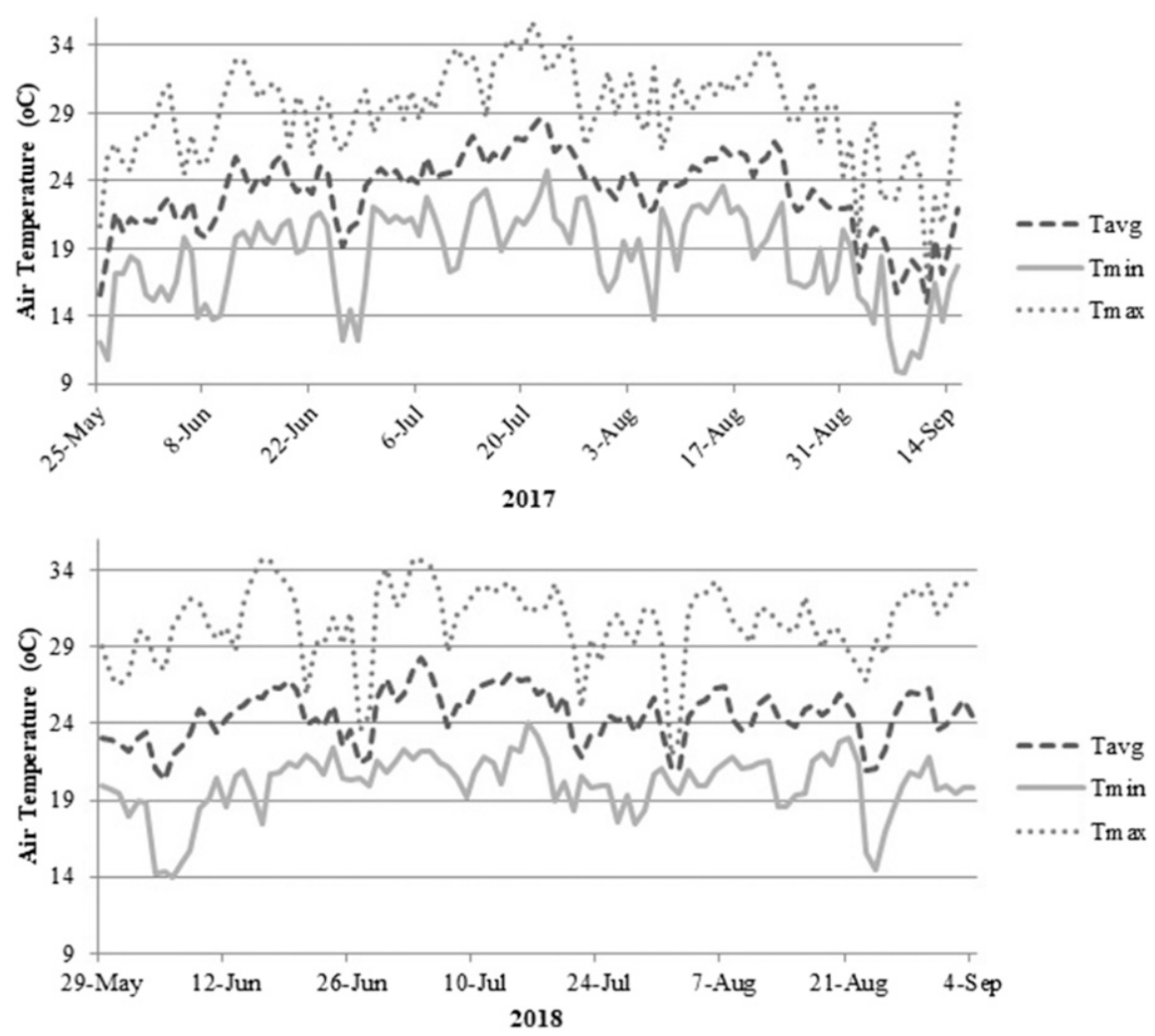

Fig. 1. Average, maximum, and minimum air temperatures over the 2017 and 2018 growing seasons in Knoxville, TN.
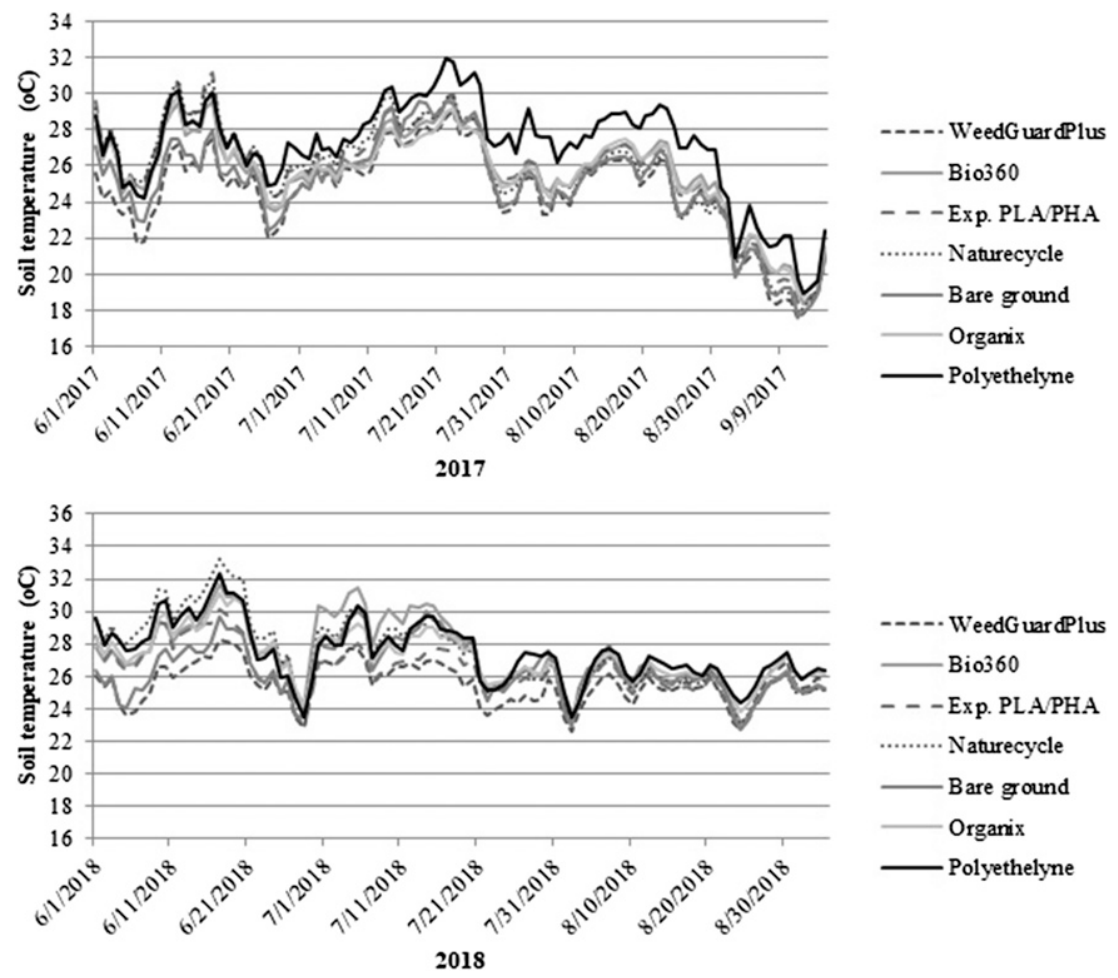

Fig. 2. Average daily soil temperatures $\left({ }^{\circ} \mathrm{C}\right)$ at $10 \mathrm{~cm}$ over the 2017 and 2018 growing seasons in Knoxville, TN. PLA = polylactic acid; PHA = polyhydroxyalkanoate.

years separate. In 2017, end of the season weed dry biomass was generally lowest for Bio360 and WGP; intermediate for bare ground, WOB, and PE; and greatest for PLA/ PHA, Organix, and Naturecycle (Table 2). In
2018 , at the midseason rating, weed dry biomass was lowest for bare ground and WGP as well as PE; intermediate for Bio360, Naturecycle, Organix, and WOB; and greatest for PLA/PHA (507 g.m ${ }^{-2}$ ) (Table 2). By late 
season 2018, the hand-weeded bare ground plots had the lowest weed dry biomass, followed by WGP and PE. Bio360, Natureycle, Organix, and WOB plots were intermediate, and PLA/PHA plots had the greatest biomass (701 g. $\mathrm{m}^{-2}$, Table 2$)$.

The most prevalent weed species by count was yellow nutsedge, followed by goosegrass (Eleusine indica L.), then redroot pigweed (Amaranthus retroflexus L.) (data not shown). Bare ground plots had the greatest species diversity, with an average range of two to six different species of weeds over the 2017 and 2018 weed rating dates (data not shown). In 2018, the early breakdown and lifting of the PLA/PHA mulch by extreme nutsedge pressure led to greater levels of weed diversity, with numbers of different species approaching the diversity in the bare ground plots ( $4-5$ species, data not shown). Early season nutsedge counts were made during PSE ratings (data for bare ground were not recorded), and counts were greater in 2018 than 2017, with PLA/PHA plots having greater counts per $\mathrm{m}^{2}$ in 2018 than all other treatments except Naturecycle. WGP plots had lower counts than all other treatments except Bio360, PE, and Organix with 0 nutsedge per $\mathrm{m}^{2}$ (Table 3 ). Comparing the end of the season data, we found that WGP plot nutsedge counts were lower than for PLA/ PHA, Naturecycle, PE, WOB, and Organix plots in 2017 and were lower than any other mulch treatment on 13 June and 21 Aug. 2018 (Table 3). For the plastic treatments, by late season 2017, PLA/PHA, Naturecycle, Organix, $\mathrm{PE}$, and WOB plots all had significant levels of nutsedge penetration (48-84 plants per $\mathrm{m}^{2}$ ) (Table 3). For the plastic treatments, by late season 2018, Bio360, PLA/PHA, Naturecycle, and Organix had the greatest nutsdege counts (163-173 plants per $\mathrm{m}^{2}$ ), followed by WOB (99 plants per $\mathrm{m}^{2}$ ) and then PE (53 plants per $\mathrm{m}^{2}$ ).

Plant health ratings. On 11 July 2017, bare ground, WGP, and WOB plots had the greatest number of healthy plants, all averaging 34 plants in the data bed (Fig. 4). Bio360, PLA/PHA, Organix, and PE plots averaged 21 to 26 healthy plants in the data bed. Naturecycle plots had the lowest number of healthy plants, with an average of 14 (Fig. 4). On 9 Aug. 2017, bare ground, Bio360, PLA/PHA, Organix, PE, WGP, and WOB plots were all statistically similar, with 28 to 34 healthy plants per data bed, whereas Naturecycle had significantly less than all other treatments with 19 plants (Fig. 4). On 3 July 2018, bare ground, PLA/PHA, WGP, and WOB plots had a greater number of healthy plants than all other treatments, with 27 to 33 plants per data bed. PE plots had the lowest number, with 7 healthy plants per data bed, but did not differ from Naturecycle and Organix plots (Fig. 4). On 14 Aug. 2018, bare ground plots had the greatest number of healthy plants with 33, although not different from WPG and WOB plots with 30 and 29, respectively. PE plots still had a lower number of healthy plants (5) than all other treatments except Organix with 9 healthy plants per data bed (Fig. 4).

Fruit yield. In 2017, total yield by weight was greatest for Bio360, bare ground, WGP, PE, WOB, and PLA/PHA plots (Table 4). All
2017

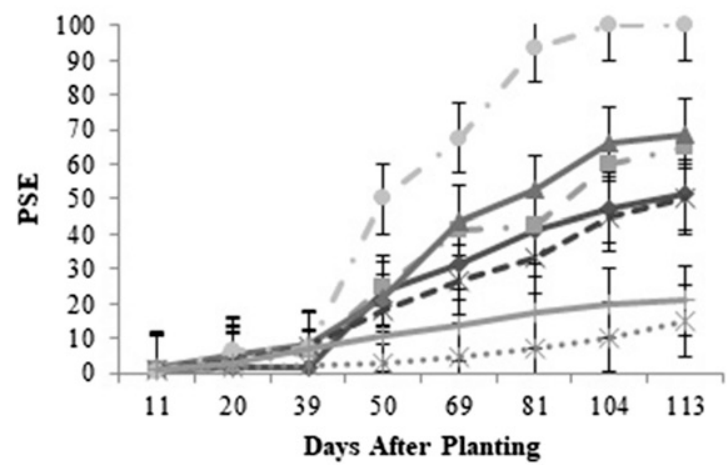

2018

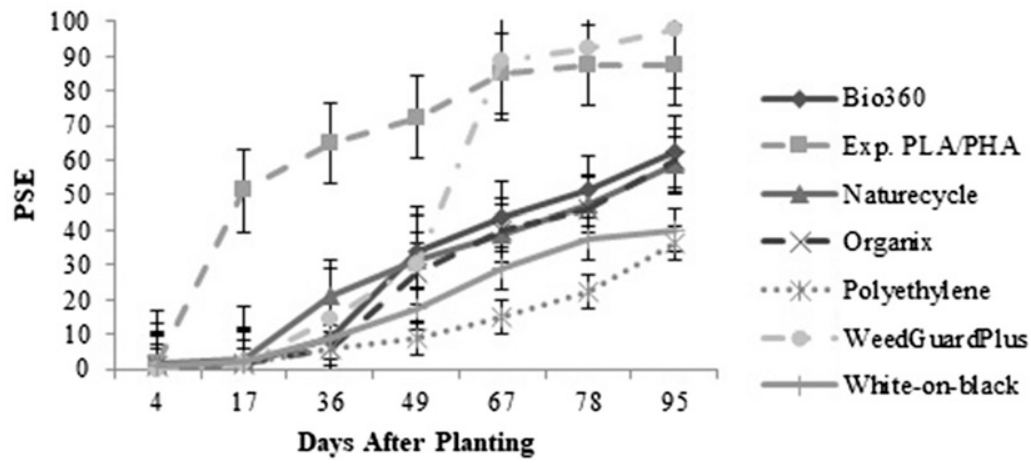

Fig. 3. Percent soil exposure (PSE) for all mulch treatments over the pepper-growing seasons in Knoxville, TN, in 2017 and 2018 . The error bars represent two sE of the mean. PSE ratings range from $0 \%$ (soil fully covered by mulch) to $100 \%$ (soil fully exposed/mulch deteriorated). Ratings were estimated in $1 \%$ increments up to $20 \%$ and in $5 \%$ increments above $20 \%$. PLA = polylactic acid; PHA = polyhydroxyalkanoate.

Table 2. Mean number of weeds and dry weight (DW) $\left(\mathrm{g} \cdot \mathrm{m}^{-2}\right)$ at early, mid-, and late season in the pepper field in Knoxville, TN, in 2017 and 2018 . Bare ground plots were hand weeded.

\begin{tabular}{|c|c|c|c|c|c|c|}
\hline Treatment & No. weeds (per & $\mathrm{DW}\left(\mathrm{g} \cdot \mathrm{m}^{-2}\right)$ & No. weeds (per & $\mathrm{DW}\left(\mathrm{g} \cdot \mathrm{m}^{-2}\right)$ & No. weeds (per & $\mathrm{DW}\left(\mathrm{g} \cdot \mathrm{m}^{-2}\right.$ \\
\hline Bare ground & $88.5 \mathrm{a}^{\mathrm{z}}$ & $30.5 \mathrm{a}$ & $34.1 \mathrm{a}$ & $28.1 \mathrm{ab}^{\mathrm{y}}$ & $38.9 \mathrm{ab}$ & $25.4 \mathrm{abc}$ \\
\hline Bio360 & $1.3 \mathrm{~d}$ & $0.3 \mathrm{~d}$ & $13.4 \mathrm{~b}$ & $28.1 \mathrm{c}$ & $37.1 \mathrm{~b}$ & $29.1 \mathrm{c}$ \\
\hline Exp PLA/PHA & $17.3 \mathrm{bc}$ & $6.3 \mathrm{bc}$ & $51.8 \mathrm{a}$ & $62.7 \mathrm{ab}$ & $68.2 \mathrm{ab}$ & $149.2 \mathrm{a}$ \\
\hline Organix & $15.1 \mathrm{bc}$ & $6.4 \mathrm{ab}$ & $58.3 \mathrm{a}$ & $63.3 \mathrm{a}$ & $84.2 \mathrm{a}$ & $90.8 \mathrm{a}$ \\
\hline $\mathrm{PE}$ & $3.0 \mathrm{bcd}$ & $1.4 \mathrm{bcd}$ & $34.1 \mathrm{a}$ & $23.7 \mathrm{ab}$ & $63.0 \mathrm{ab}$ & $66.7 \mathrm{ab}$ \\
\hline WeedGuardPlus & $2.6 \mathrm{~d}$ & $0.8 \mathrm{~cd}$ & $6.5 \mathrm{~b}$ & $10.1 \mathrm{bc}$ & $12.1 \mathrm{c}$ & $35.9 \mathrm{bc}$ \\
\hline 2018 & \multicolumn{2}{|c|}{13 June } & \multicolumn{2}{|c|}{18 July } & \multicolumn{2}{|c|}{21 Aug } \\
\hline Bare ground & $11.2 \mathrm{de}$ & $0.5 \mathrm{~b}$ & $41.9 \mathrm{~cd}$ & $16.6 \mathrm{de}$ & $15.5 \mathrm{c}$ & $15.8 \mathrm{~d}$ \\
\hline Bio360 & $23.7 \mathrm{bcd}$ & $1.9 \mathrm{~b}$ & $83.7 \mathrm{bc}$ & $27.0 \mathrm{~cd}$ & $165.3 \mathrm{a}$ & $210.5 \mathrm{ab}$ \\
\hline Exp PLA/PHA & $144.2 \mathrm{a}$ & $16.5 \mathrm{a}$ & $309.5 \mathrm{a}$ & $506.5 \mathrm{a}$ & $179.6 \mathrm{a}$ & $701.2 \mathrm{a}$ \\
\hline Naturecycle & $29.4 \mathrm{bc}$ & $3.4 \mathrm{ab}$ & $161.9 \mathrm{ab}$ & $116.1 \mathrm{abc}$ & $238.7 \mathrm{a}$ & $329.9 \mathrm{ab}$ \\
\hline Organix & $18.1 \mathrm{bcd}$ & $2.2 \mathrm{~b}$ & $159.7 \mathrm{ab}$ & $63.1 \mathrm{bc}$ & $172.7 \mathrm{a}$ & $275.3 \mathrm{ab}$ \\
\hline $\mathrm{PE}$ & $14.7 \mathrm{cde}$ & $2.5 \mathrm{~b}$ & $29.8 \mathrm{~d}$ & $17.9 \mathrm{de}$ & $52.7 \mathrm{~b}$ & $85.7 \mathrm{bc}$ \\
\hline
\end{tabular}

${ }^{\mathrm{z}}$ Treatment means with the same letter within a given column are not significantly different (Fisher's least significant difference at $\alpha=0.05$ ).

${ }^{\mathrm{y}}$ Mean separation letters are taken from the transformed analysis; however, raw means are reported.

PLA = polylactic acid; $\mathrm{PHA}=$ polyhydroxyalkanoate $\mathrm{PE}=$ polyethylene . 
Table 3. Average counts of nutsedge plants (number of plants per $\mathrm{m}^{2}$ ) in plots by treatment for each weed rating date and for two of the PSE rating dates over the pepper-growing seasons in 2017 and 2018 in Knoxville, TN. Bare ground plots were hand weeded.

\begin{tabular}{|c|c|c|c|c|c|c|c|c|}
\hline \multirow[b]{2}{*}{ Treatment } & \multicolumn{8}{|c|}{ Number of nutsedge plants per $\mathrm{m}^{2}$} \\
\hline & 5 June 2017 & 19 June 2017 & 19 July 2017 & 6 Sept. 2017 & 1 June $2018^{z}$ & 13 June 2018 & 18 July 2018 & 21 Aug. 2018 \\
\hline Bio360 & 2 & $1 \mathrm{c}$ & $13 \mathrm{bc}$ & $34 \mathrm{bc}$ & $6 \mathrm{~cd}$ & $16 \mathrm{~b}$ & $82 \mathrm{a}$ & $165 \mathrm{a}$ \\
\hline Exp PLA/PHA & 5 & $17 \mathrm{a}$ & $51 \mathrm{a}$ & $67 \mathrm{ab}$ & $24 \mathrm{a}$ & $113 \mathrm{a}$ & $261 \mathrm{a}$ & $169 \mathrm{ab}$ \\
\hline Organix & 11 & $14 \mathrm{ab}$ & $58 \mathrm{a}$ & $84 \mathrm{a}$ & $9 \mathrm{bcd}$ & $18 \mathrm{~b}$ & $159 \mathrm{a}$ & $173 \mathrm{a}$ \\
\hline $\mathrm{PE}$ & 3 & $3 a b c$ & $34 \mathrm{a}$ & $63 \mathrm{ab}$ & $6 \mathrm{~cd}$ & $15 \mathrm{~b}$ & $30 \mathrm{~b}$ & $53 \mathrm{c}$ \\
\hline WeedGuardPlus & 0 & $2 \mathrm{bc}$ & $1 \mathrm{c}$ & $6 \mathrm{c}$ & $0 \mathrm{~d}$ & $0 \mathrm{c}$ & $11 \mathrm{~b}$ & $10 \mathrm{~d}$ \\
\hline
\end{tabular}

${ }^{\mathrm{z}}$ Counts taken during PSE ratings, so data not available for bare ground treatment.

${ }^{\mathrm{y}}$ Treatment means with the same letter within a given column are not significantly different (Fisher's least significant difference at $\alpha=0.05$ ).

$\mathrm{PSE}=$ percent soil exposure; $\mathrm{PLA}=$ polylactic acid $\mathrm{PHA}=$ polyhydroxyalkanoate $; \mathrm{PE}=$ polyethylene.

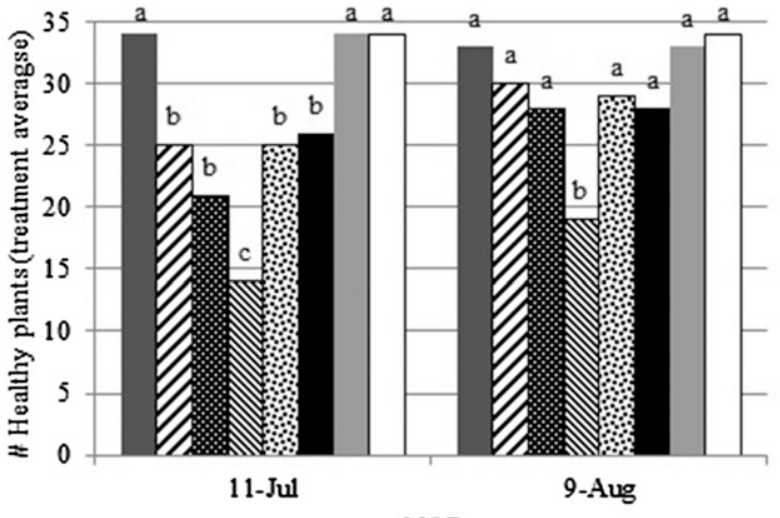

2017

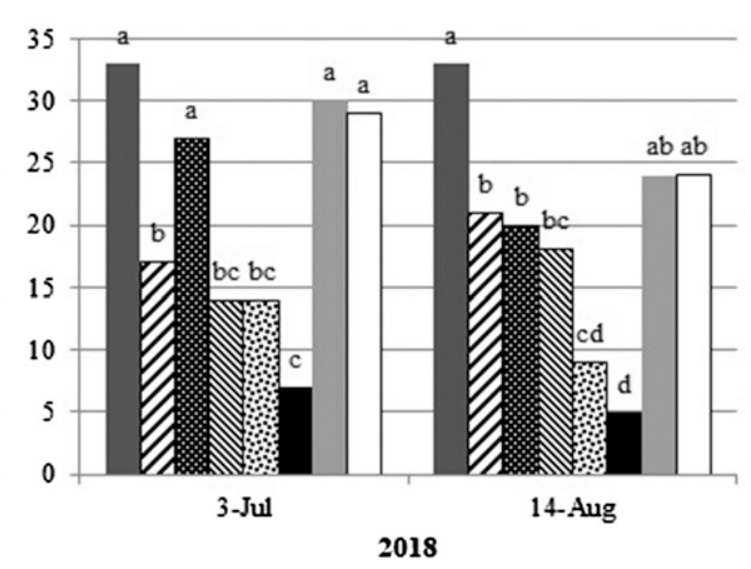

- Bare ground

$\triangle \mathrm{Bio} 360$

Exp. PLA/PHA

\$Naturecycle

EOrganix

- Polyethylene

" WeedG uardPlus

$\square$ White-on-black

2018

Fig. 4. Number of healthy pepper plants in the data collection beds by a visual rating during the 2017 and 2018 pepper-growing seasons in Knoxville, TN. Treatment means with the same letter within a given date are not significantly different. Treatment means compared using Fisher's least significant difference at $\alpha=0.05$. PLA $=$ polylactic acid; PHA $=$ polyhydroxyalkanoate.

treatments except Organix had significantly greater yields than Naturecycle. In 2018, bare ground and WGP plots had greater yields than all other treatments, except WOB (Table 4). Percent of unmarketable fruit by weight was greater in 2018 across all treatments compared with 2017 (Table 4).

There were no significant differences among treatments for extra large and jumbo fruit, and yields for these categories were very low over both years (data not shown). In 2017, Bio360 plots had a greater yield of large fruit than Naturecycle, Organix, and WOB plots. WGP had greater yields of small fruit compared with PLA/PHA, Naturecycle, and Organix (Table 5). WOB, WGP, bare ground, and $\mathrm{PE}$ plots had the greatest yields of choppers among treatments (for WOB this was mostly due to pancaking of fruit), whereas PLA/PHA and Naturecycle had the lowest yield of choppers (Table 5). In 2018, the trend with fruit sizes was different from in 2017, with all treatments having lower yields of large fruit. Bare ground, WOB, and WGP plots had the greatest yields across size categories, whereas PE had the lowest yields across categories (Table 5). Size classes by fruit number followed the same trends as size classes by weight (data not shown).

Total pepper harvest for individual harvest dates are shown by weight in Table 6 .

Table 4. Total fruit yields and percent unmarketable by weight (tons per hectare) for all harvest dates for the 2017 and 2018 pepper-growing seasons in Knoxville, TN.

\begin{tabular}{lcccc}
\hline & \multicolumn{4}{c}{ Season total fruit yield by wt } \\
\cline { 2 - 5 } Treatment & $\begin{array}{c}2017 \text { yield } \\
\left(\mathrm{t} \cdot \mathrm{ha}^{-1}\right)\end{array}$ & $\begin{array}{c}2018 \text { yield } \\
\left(\mathrm{t} \cdot \mathrm{ha}^{-1}\right)\end{array}$ & $\begin{array}{c}\text { \% unmarketable } \\
2017\end{array}$ & $\begin{array}{c}\text { \% unmarketable } \\
2018\end{array}$ \\
\hline Bare ground & $35.8 \mathrm{ab}^{\mathrm{z}}$ & $24.4 \mathrm{a}$ & 5.7 & 19.3 \\
Bio360 & $37.9 \mathrm{a}$ & $8.7 \mathrm{bc}$ & 8.9 & 28.2 \\
Exp. PLA/PHA & $27.7 \mathrm{ab}$ & $7.4 \mathrm{bc}$ & 10.5 & 30.3 \\
Naturecycle & $17.3 \mathrm{c}$ & $8.7 \mathrm{bc}$ & 13.0 & 23.1 \\
Organix & $26.8 \mathrm{bc}$ & $5.4 \mathrm{c}$ & 10.8 & 33.3 \\
PE & $33.8 \mathrm{ab}$ & $1.3 \mathrm{c}$ & 11.9 & 31.6 \\
WeedGuardPlus & $34.9 \mathrm{ab}$ & $22.1 \mathrm{a}$ & 9.7 & 31.4 \\
White-on-black & $33.7 \mathrm{ab}$ & $15.7 \mathrm{ab}$ & 13.3 & 0.5069 \\
$P$ value & 0.005 & $<0.0001$ & 0.6296 & \\
\hline
\end{tabular}

${ }^{\mathrm{z}}$ Treatment means with the same letter within a given column are not significantly different (Fisher's least significant difference at $\alpha=0.05$ ).

PLA = polylactic acid PHA = polyhydroxyalkanoate PE = polyethylene.

Peak yields were in mid-August in both years (Table 6). Yields in 2017 were declining midseason as shown by the dip on 28 Aug. 2017 but rose again in Sept. 2017 (Table 6). This pattern was not seen in 2018 with yields lower for most treatments all season, and harvests ending 3 weeks sooner than in 2017 (Table 6).

\section{Discussion}

While the early season soil warming effect of PE mulch can increase yields of bell pepper (e.g., Canul-Tun et al., 2017; DíazPérez, 2010), in certain climates and conditions, black-colored mulches can decrease yields and possibly even degrade soil (DíazPérez, 2010; Roberts and Anderson, 1994). There was not a clear difference in yield by color of mulch in 2017, but in 2018 all of the black-colored treatments had lower yields than the bare ground, WOB, and WGP treatments, with the lowest yields in Organix and PE. PE likely had the lowest yield in 2018 because it stayed the most intact and many of the plants failed to establish because 
Table 5. Season total (all harvest dates) marketable pepper fruit by size classes by weight (tons per hectare) for the 2017 and 2018 pepper-growing seasons in Knoxville, TN.

\begin{tabular}{|c|c|c|c|c|c|c|c|c|}
\hline \multirow{2}{*}{ Treatment } & \multicolumn{8}{|c|}{ Marketable size classes-season total fruit (t.ha $\left.{ }^{-1}\right)$} \\
\hline & \multicolumn{4}{|c|}{2017} & \multicolumn{4}{|c|}{2018} \\
\hline Bare ground & $8.02 \mathrm{ab}^{2}$ & 8.85 & $10.62 \mathrm{ab}$ & $5.07 \mathrm{ab}$ & $4.68 \mathrm{a}$ & $5.83 \mathrm{a}$ & $4.88 \mathrm{a}$ & $3.67 \mathrm{a}$ \\
\hline Naturecycle & $4.77 \mathrm{c}$ & 4.01 & $3.74 \mathrm{c}$ & $1.77 \mathrm{~d}$ & $1.18 \mathrm{bc}$ & $2.15 \mathrm{bcd}$ & $1.76 \mathrm{bc}$ & $1.06 \mathrm{~cd}$ \\
\hline Organix & $6.14 b c$ & 5.69 & $6.19 b c$ & $3.98 \mathrm{~b}$ & $0.92 \mathrm{bc}$ & $1.01 \mathrm{~cd}$ & $1.03 \mathrm{bc}$ & $0.58 \mathrm{~cd}$ \\
\hline $\mathrm{PE}$ & $6.89 \mathrm{abc}$ & 7.07 & $9.21 \mathrm{ab}$ & $4.67 \mathrm{ab}$ & $0.24 \mathrm{c}$ & $0.14 \mathrm{~d}$ & $0.04 \mathrm{c}$ & $0.23 \mathrm{~d}$ \\
\hline$P$ value & 0.04 & 0.06 & 0.04 & $<0.0001$ & 0.0006 & 0.002 & 0.01 & $<0.0001$ \\
\hline
\end{tabular}

${ }^{\mathrm{z}}$ Treatment means with the same letter within a given column are not significantly different (Fisher's least significant difference at $\alpha=0.05$ ).

PLA = polylactic acid; PHA = polyhydroxyalkanoate; $\mathrm{PE}=$ polyethylene.

Table 6. Total pepper harvest weight (tons per hectare) by harvest date over the 2017 and 2018 pepper-growing seasons in Knoxville, TN.

\begin{tabular}{|c|c|c|c|c|c|c|c|c|c|c|c|c|c|c|c|c|}
\hline \multirow[b]{3}{*}{ Treatment } & \multicolumn{16}{|c|}{ Total harvest (t.ha $\left.{ }^{-1}\right)$ (avg per plot by date) } \\
\hline & \multicolumn{9}{|c|}{2017} & \multicolumn{7}{|c|}{2018} \\
\hline & 26 July & 3 Aug. & 10 Aug. & 15 Aug. & 22 Aug. & 28 Aug. & 5 Sept. & 11 Sept. & 19 Sept. & 16 July & 23 July & 30 July & 6 Aug. & 13 Aug. & 20 Aug. & 27 Aug. \\
\hline Bare ground & 0.0 & $0.9 \mathrm{~cd}^{2}$ & $5.2 \mathrm{a}$ & $3.7 \mathrm{a}$ & 5.6 & 2.9 & 2.9 & 5.0 & 9.5 & 0.9 & $3.8 \mathrm{a}$ & 2.1 & $3.7 \mathrm{a}$ & $5.3 \mathrm{a}$ & $2.6 \mathrm{a}$ & $1.3 \mathrm{a}$ \\
\hline Exp. PLA/PHA & 0.5 & $1.7 \mathrm{bc}$ & $5.5 \mathrm{a}$ & $1.4 \mathrm{bc}$ & 4.4 & 1.2 & 2.0 & 4.9 & 6.0 & 0.1 & $1.5 \mathrm{~b}$ & 1.2 & $0.6 \mathrm{bc}$ & $1.1 \mathrm{~cd}$ & $0.5 \mathrm{bc}$ & $0.2 b c$ \\
\hline Naturecycle & 0.2 & $0.4 \mathrm{~d}$ & $1.7 \mathrm{~b}$ & $0.7 \mathrm{c}$ & 1.7 & 1.0 & 2.2 & 3.0 & 6.5 & 0.7 & $1.3 \mathrm{~b}$ & 0.7 & $0.6 \mathrm{bc}$ & $2.6 \mathrm{bc}$ & $0.6 \mathrm{bc}$ & $0.2 b c$ \\
\hline Organix & 0.7 & $3.0 \mathrm{ab}$ & $4.2 \mathrm{a}$ & $2.7 \mathrm{ab}$ & 4.7 & 0.9 & 1.7 & 4.0 & 5.8 & 0.4 & $1.1 \mathrm{~b}$ & 0.9 & $0.2 \mathrm{~cd}$ & $0.4 \mathrm{de}$ & $0.4 \mathrm{bc}$ & $0.2 b c$ \\
\hline White-on-black & 0.3 & $4.1 \mathrm{ab}$ & $11.1 \mathrm{a}$ & $4.6 \mathrm{a}$ & 4.8 & 0.5 & 1.7 & 2.0 & 4.7 & 0.8 & $2.3 \mathrm{~b}$ & 1.9 & $1.3 \mathrm{~b}$ & $2.7 \mathrm{ab}$ & $1.0 \mathrm{~b}$ & $0.8 \mathrm{ab}$ \\
\hline$P$ value & 0.05 & 0.001 & 0.04 & 0.003 & 0.35 & 0.26 & 0.76 & 0.05 & 0.59 & 0.26 & 0.0001 & 0.06 & $<0.0001$ & $<0.0001$ & 0.0002 & 0.01 \\
\hline
\end{tabular}

${ }_{\mathrm{z}}^{\mathrm{z}}$ Treatment means with the same letter within a given column are not significantly different (Fisher's least significant difference at $\alpha=0.05$ ).

PLA = polylactic acid; $\mathrm{PHA}=$ polyhydroxyalkanoate; $\mathrm{PE}=$ polyethylene .

of heat; this resulted in more mulch surface exposed to the sun than other treatments, contributing to greater soil temperatures. Díaz-Pérez (2010) observed that bell pepper fruit yield decreased with mean seasonal root zone temperatures (RZTs) above $27.5{ }^{\circ} \mathrm{C}$, and that the optimal range of RZT for bell pepper fruit yield is 25 to $27.5^{\circ} \mathrm{C}$ or less. In this study in both years, plants in the blackcolored plots experienced more transplant shock than plants in bare ground, WOB, and WPG treatments. In 2017, most plants in the black-colored treatments recovered; however, in 2018, many did not recover, and yields suffered for all black-colored mulches. This trend was likely due to excessive RZT as described previously because soil temperatures at $10 \mathrm{~cm}$ for all black mulches were above this $27.5{ }^{\circ} \mathrm{C}$ threshold from 1 June to 25 June in 2018 (24 d), whereas in 2017, this threshold was only surpassed from 11 June to 19 June $(8 \mathrm{~d})$. Soil temperatures did rise above the $27.5{ }^{\circ} \mathrm{C}$ threshold again in July 2017 , but it was after plants were well established. Similarly, Kader et al. (2017) found that soybean yield in a region experiencing very hot summer weather was greatest with a paper mulch compared with black PE mulch because of the root zone cooling effects. During the critical time when the pepper transplants were becoming established in June, average, minimum, and maximum air temperatures were greater in 2018 (24.0, 19.3, and $30.4{ }^{\circ} \mathrm{C}$, respectively) than in 2017 (22.8, 17.7 , and $28.9^{\circ} \mathrm{C}$, respectively). Roberts and Anderson (1994) report that pepper fruit set is reduced when temperatures exceed $30{ }^{\circ} \mathrm{C}$; and in the current study, air temperatures peaked above $30{ }^{\circ} \mathrm{C}$ for $52 \mathrm{~d}$ in 2017 (MayAugust) and $63 \mathrm{~d}$ in 2018 (May-August). Similarly, López-Marín et al. (2012) noted that regulating heat stress increased the marketable yield of bell pepper. Vos and Sumarni (1997) speculated that poor pepper plant establishment in their trials was likely due to excessive heat stress in some of their plasticmulched plots. Mulch with the white surface facing up has been found to cool soil temperatures compared with clear- and blackcolored mulches (e.g., Decoteau, 1989; Heißner et al., 2005), and we did find that WOB had greater yields for some harvest dates in 2018 than any of the black mulch treatments. Limpus et al. (2012) report that many growers in Australia are beginning to use WOB mulches year round to prevent seedling damage from hot spells. Decoteau (1989) concludes that mulch color selection for a particular crop may depend on the season and geographic area, which we found to be true in this experiment.

In the current study, we had to balance crop planting with the concurrent soilmonitoring component of this experiment (2015-18), forcing later transplanting than ideal for eastern Tennessee, which probably also contributed to heat stress in the blackcolored mulch plots. Similarly, Hochmuth and Hochmuth (1994) demonstrated that pepper yields in Florida were greater with paper mulches than in PE in 1 year of their experiment, noting that lower yields on black mulches that year may have been due to a later planting date and resulting heat stress.

Another reason for the greater yields in WGP and bare ground in 2018 was likely due to nutsedge pressure. The bare ground plots were hand weeded, which has been shown to be an effective, although very expensive, method to control nutsedge (Bangarwa et al., 2010). Morales-Payan et al. (1997) and Peerzada (2017) report that mechanical and cultural control of nutsedge through cultivation and other means usually is not economical or realistic, and an intensive, integrated approach is vital. There are reports that a stale seedbed method and/or repeated hand weeding or hoeing are effective in reducing nutsedge pressure (Wang et al., 2009). Recommended practices such as fumigation and stale seedbed/frequent tillage, however, were not available for use in this study because it would have interfered with the concurrent soil-monitoring experiment (Ghimire et al., 2018). Control with herbicides is difficult because most currently available herbicides do not kill the dormant tubers (Peerzada, 2017), and nutsedge control is only marginal (Bangarwa et al., 2009). Similarly, Adcock et al. (2008) found that preemergence herbicides did not reduce nutsedge penetration of PE mulch. Shading by an established crop such as cucurbits can reduce nutsedge tuber expansion (Johnson and Mullinix, 2008; Morales-Payan et al., 1997). We observed this shading effect as vigorous pumpkin vine growth suppressed, but did not eliminate, nutsedge in the 2015 to 
2016 years of this experiment (Ghimire et al., 2018). This set the stage for explosive nutsedge growth and expansion in the 2017 and 2018 growing seasons with pepper as the crop, which provided much less canopy shade. Santos et al. (2007) observed that even low densities of yellow nutsedge can cause significant reductions in bell pepper yield, especially if the weed emerges early in the growing season, as it did in this experiment with nutsedge already penetrating mulch by the planting date. Similarly, Morales-Payan et al. (1997) observed that bell pepper yield decreased linearly with increasing purple nutsedge densities causing yield losses of up to $32 \%$ in bell pepper. Anzalone et al. (2010) observed that even though the PE mulch and BDMs were the same thickness, the nutsedge seemed to penetrate the BDM more easily. They speculate that this may be due to less resistance to perforation by the BDM or possibly weakness due to the beginning of biodegradation. This experiment seems to support both of these ideas, as nutsedge penetrated the PE mulch and BDMs within 1 week of laying both years, with greater numbers in 2018. It appears that for PLA/PHA and Naturecycle, less resistance may have been the cause, as they had the greatest counts of nutsedge by 1 June 2018 . Alternatively, the lower counts of early season nutsedge in Bio360, Organix, and WOB seem to support the idea that BDMs are more easily penetrated by nutsedge than $\mathrm{PE}$ because of weakness and lower plasticity later in the season as they begin to biodegrade.

The WGP prevented emergence of nutsedge, whereas nutsedge penetrated all of the plastic mulches. Similar to Anzalone et al. (2010), we observed that the only nutsedge found in paper mulch beds emerged from planting holes or other tears or rips and that the weed did not penetrate intact paper mulch. One disadvantage of paper mulch is that it often breaks down quickly along the buried edges so that it is more easily damaged by wind than PE mulch or BDMs (Anzalone et al., 2010), and we did have some wind damage in these experiments; however, it was not extensive. If edge degradation does not happen until later in the season, often the crop is large enough to hold the mulch in place despite winds (Anzalone et al., 2010). Olsen and Gounder (2001) also found that tearing and wind damage were not significant problems in using paper mulch for pepper production in Australia. Coolong (2010) tested various paper mulches for summer squash production and concluded that, as with other types of mulch, the effectiveness of paper mulches depends on crop and environmental conditions.

This study shows that paper mulch performed better for pepper production than black plastic mulches (PE or BDM) in our area with hot summers and fields infested with nutsedge for midseason planting. WOB mulch was beneficial in this experiment for its cooling effect compared with the black mulches, resulting in better pepper plant health; however, it was not able to withstand nutsedge penetration, which significantly lowered yield for this BDM treatment. As others have noted, hand weeding can successfully control nutsedge; however, this can be very expensive depending on labor costs in the area. Potential barriers to paper mulch use need to be addressed. The WGP paper mulch used in this project is commercially available; although shipping costs can be expensive and due to the weight of the mulch, the rolls are shorter $(152 \mathrm{~m} /$ roll $)$ so more rolls are needed to cover the same area compared with PE or BDMs (610-1219 m/roll). Once mulch-laying equipment was properly adjusted, time to lay the WGP creped paper mulch was the same as any of the other mulch treatments. We found that paper mulch stayed intact long enough to provide weed control during the critical period (first 4-6 weeks after planting), similar to the findings of Shogren and Hochmuth (2004) with watermelon in Florida. Others (Haapala et al., 2014) have pointed out issues with ripping, wind damage, and early breakdown along the buried edge of paper mulch. We experienced all of those issues in this experiment, but they were not severe and the advantages of the root zone cooling effect and the nutsedge control outweighed these effects. However, for an earlyseason crop, WGP might be less effective than black-colored mulches if soil warming is desired. In addition, in both years, there was no visible paper mulch left by the end of the season, so there were no disposal costs or mulch fragments remaining in the soil. In observations made every spring and fall after tillage, we did find some small fragments of BDMs remaining, which over time may affect yield in some way, but there have not been enough long-term studies with BDMs to make definitive conclusions. We found that for areas with hot summers and nutsedge weed pressure, paper mulch performed better than any of the plastic mulches tested. As others have noted (e.g., Kader et al., 2017), it is important for growers to assess their crop, season, climate, and weed community when choosing a mulch product.

\section{Literature Cited}

Adcock, C.W., W.G. Foshee, G.R. Wehtje, and C.H. Gilliam. 2008. Herbicide combinations in tomato to prevent nutsedge (Cyperus esculentus) punctures in plastic mulch for multicropping systems. Weed Technol. 22:136-141.

Anzalone, A., A. Cirujeda, J. Aibar, G. Pardo, and C. Zaragoza. 2010. Effect of biodegradable mulch materials on weed control in processing tomatoes. Weed Technol. 24:369-377.

Arguez, A., I. Durre, S. Applequist, M. Squires, R. Vose, X. Yin, and R. Bilotta. 2010. NOAA's U.S. Climate Normals (1981-2010). Knoxville Experimental Station, TN US GHCND:U SC00404946. NOAA National Centers for Environmental Information. 29 June 2016. $<$ https://www.ncdc.noaa.gov/>.

Bangarwa, S.K., J.K. Norsworthy, and E.E. Gbur. 2009. Cover crop and herbicide combinations for weed control in polyethylene-mulched bell pepper. HortTechnology 19:405-410.

Bangarwa, S.K., J.K. Norsworthy, R.L. Rainey, and E.E. Gbur. 2010. Economic returns in plasticulture tomato production from crucifer cover crops as a methyl bromide alternative for weed management. HortTechnology 20:764-771.

Bläsing, M. and W. Amelung. 2018. Plastics in soil: Analytical methods and possible sources. Sci. Total Environ. 612:422-435.

Brodhagen, M., J.R. Goldberger, D.G. Hayes, D.A. Inglis, T.L. Marsh, and C. Miles. 2017. Policy considerations for limiting unintended residual plastic in agricultural soils. Environ. Sci. Policy 69:81-84.

Canul-Tun, C.E., L. Ibarra-Jiménez, L.A. ValdezAguilar, A.J. Lozano-del Río, A. Cárdenas-Flores, A. Zermeño-González, C.J. Lozano-Cavazos, J.H. Valenzuela-Soto, and V. Torres-Olivar. 2017. Influence of colored plastic mulch on soil temperature, growth, nutrimental status, and yield of bell pepper under shade house conditions. J. Plant Nutr. 40:1083-1090.

Cirujeda, A., A. Anzalone, J. Aibar, M.M. Moreno, and C. Zaragoza. 2012. Purple nutsedge (Cyperus rotundus L.) control with paper mulch in processing tomato. Crop Prot. 39:66-71.

Coolong, T. 2010. Performance of paper mulches using a mechanical plastic layer and water wheel transplanter for the production of summer squash. HortTechnology 20:319-324.

Decoteau, D.R. 1989. Mulch surface color affects yield of fresh-market tomatoes. J. Amer. Soc. Hort. Sci. 114:216-219.

Díaz-Pérez, J.C. 2010. Bell pepper (Capsicum annum L.) grown on plastic film mulches: Effects on crop microenvironment, physiological attributes, and fruit yield. HortScience 45:1196-1204.

Gao, H., C. Yan, Q. Liu, W. Ding, B. Chen, and Z. Li. 2019. Effects of plastic mulching and plastic residue on agricultural production: A metaanalysis. Sci. Total Environ. 651:484-492.

Geyer, R., J.R. Jambeck, and K.L. Law. 2017. Production, use, and fate of all plastics ever made. Sci. Adv. 3:E1700782.

Ghimire, S., A.L. Wszelaki, J.C. Moore, D.A. Inglis, and C. Miles. 2018. The use of biodegradable mulches in pie pumpkin crop production in two diverse climates. HortScience 53:288-294.

Haapala, T., P. Palonen, A. Korpela, and J. Ahokas. 2014. Feasibility of paper mulches in crop production-a review. Agr. Food Sci. 23:60-79.

He, L., G. Gielen, N.S. Bolan, X. Zhang, H. Qin, H. Huang, and H. Wang. 2015. Contamination and remediation of phthalic acid esters in agricultural soils in China: A review. Agron. Sustain. Dev. 35:519-534.

Heißner, A., S. Schmidt, and B. von Elsner. 2005. Comparison of plastic films with different optical properties for soil covering in horticulture: Test under simulated environmental conditions. J. Sci. Food Agr. 85:539-548.

Hochmuth, B. and G. Hochmuth. 1994. Responses of pepper and watermelon to paper and polyethylene mulches in two spring seasons in north Florida. Presented at the Proc. Florida State Hort. Soc., pp. 102-102.

Holm, L.G., D.L. Plucknett, J.V. Pancho, and J.P. Herberger. 1977. The World's Worst Weeds: Distribution and Biology. University Press of Hawaii, Honolulu.

Jambeck, J.R., R. Geyer, C. Wilcox, T.R. Siegler, M. Perryman, A. Andrady, R. Narayan, and K.L. Law. 2015. Plastic waste inputs from land into the ocean. Science 347:768-771.

Johnson, W.C. and B.G. Mullinix. 2008. Cultural control of yellow nutsedge (Cyperus esculentus) in transplanted cantaloupe (Cucumis melo) by varying application timing and type of thin-film mulches. Crop Prot. 27:735-739. 
Kader, M.A., M. Senge, M.A. Mojid, and K. Nakamura. 2017. Mulching type-induced soil moisture and temperature regimes and water use efficiency of soybean under rain-fed condition in central Japan. Intl. Soil Water Conservation Res. 5:302-308.

Kasirajan, S. and M. Ngouajio. 2012. Polyethylene and biodegradable mulches for agricultural applications: A review. Agron. Sustain. Dev. 32:501-529.

Lamont, W. 2005. Plastics: Modifying the microclimate for the production of vegetable crops. HortTechnology 15:477-481.

Limpus, S., S. Heisswolf, D. Kreymborg, R. Wright, W. Hall, and S. Guerrini. 2012. Comparison of biodegradable mulch products to polyethylene in irrigated vegetable, tomato and melon crops. Final report for Horticulture Australia Limited Project MT09068. Sydney, Australia.

López-Marín, J., A. Gálvez, A. González, C. EgeaGilabert, and J.A. Fernández. 2012. Effect of shade on yield, quality and photosynthesisrelated parameters of sweet pepper plants. Acta Hort. 956:545-552.

Morales-Payan, J.P., B.M. Santos, W.M. Stall, and T.A. Bewick. 1997. Effects of purple nutsedge (Cyperus rotundus) on tomato (Lycopersicon esculentum) and bell pepper (Capsicum annuum) vegetative growth and fruit yield. Weed Technol. 11:672-676.

Motis, T.N., S.J. Locascio, J.P. Gilreath, and W.M. Stall. 2003. Season-long interference of yellow nutsedge (Cyperus esculentus) with polyethylenemulched bell pepper (Capsicum annuum). Weed Technol. 17:543-549.
Motis, T.N., S.J. Locascio, and J.P. Gilreath. 2004. Critical yellow nutsedge-free period for polyethylene-mulched bell pepper. HortScience 39:10451049.

National Oceanic and Atmospheric Administration. 2018. National Centers for Environmental Education. 12 Oct. 2018. <https://www.ncdc.noaa.gov/ data-access $>$.

Olsen, J.K. and R.K. Gounder. 2001. Alternatives to polyethylene mulch film - a field assessment of transported materials in capsicum (Capsicum annuum L.). Austral. J. Expt. Agr. 41:93103.

Peerzada, A.M. 2017. Biology, agricultural impact, and management of Cyperus rotundus L.: The world's most tenacious weed. Acta Physiol. Plant. 39:270.

Rillig, M.C. 2012. Microplastic in terrestrial ecosystems and the soil? Environ. Sci. Technol. 46:6453-6454.

Roberts, B.W. and J.A. Anderson. 1994. Canopy shade and soil mulch affect yield and solar injury of bell pepper. HortScience 29:258-260.

Santos, B.M., J.P. Gilreath, C.E. Esmel, and M.N. Siham. 2007. Effects of yellow and purple nutsedge time of establishment on their distance of influence on bell pepper. HortTechnology 17:305-307.

Saxton, A.M. 2010. danda.sas: Design and analysis macro collection, version 1.29. Univ. Tennessee, Knoxville, TN.

Shogren, R.L. and M. David. 2006. Biodegradable paper/polymerized vegetable oil mulches for tomato and pepper production. J. Appl. Hort 8:12-14.
Shogren, R.L. and R.C. Hochmuth. 2004. Field evaluation of watermelon grown on paperpolymerized vegetable oil mulches. HortScience 39:1588-1591.

Steinmetz, Z., C. Wollmann, M. Schaefer, C. Buchmann, J. David, J. Tröger, K. Muñoz, O. Frör, and G.E. Schaumann. 2016. Plastic mulching in agriculture. Trading short-term agronomic benefits for long-term soil degradation? Sci. Total Environ. 550:690-705.

United States Department of Agriculture, National Agricultural Statistics Service. 2018. Quick Stats. 8 Oct. 2018. <https://quickstats.nass. usda.gov/results/A1180307-79ED-3BEE-A3E48DAB1EC5E683? pivot=short_desc $>$.

Vos, J.G.M. and N. Sumarni. 1997. Integrated crop management of hot pepper (Capsicum spp.) under tropical lowland conditions: Effects of mulch on crop performance and production. $\mathrm{J}$. Hort. Sci. 72:415-424.

Wang, G., M.E. McGiffen, E.J. Ogbuchiekwe, and L. Butler. 2009. Economic return of purple and yellow nutsedge management in vegetable production of southern California. Crop Prot. 28: 319-326.

Wang, J., Y. Luo, Y. Teng, W. Ma, P. Christie, and Z. Li. 2013. Soil contamination by phthalate esters in Chinese intensive vegetable production systems with different modes of use of plastic film. Environ. Pollut. 180:265-273.

Webster, T.M. 2005. Patch expansion of purple nutsedge (Cyperus rotundus) and yellow nutsedge (Cyperus esculentus) with and without polyethylene mulch. Weed Sci. 53:839845 . 